\section{Diálogos literários na Lusofonia}

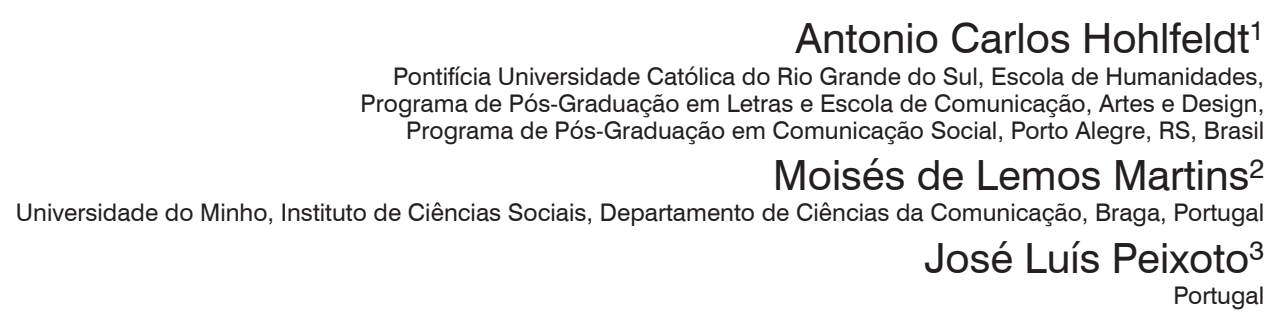

Professor titular na Pontifícia Universidade Católica do Rio Grande do Sul - PUCRS. Com experiência nas áreas de Letras e Comunicação Social, atua principalmente no campo das artes cênicas, comunicaçãa social e teoria da comunicação. (10) https://orcid. org/0000-0001-5284-8730.

E-mall. a_hohilela@yahoo.com.br

Professor Catedrático do Departamento de Ciências da Comunicaçáo da Universidade do de Comunicação e Sociedade (CECS), que fundou em 2001, e conta com publicaçōes no campo da sociologia da cultura, semiótica social, sociologia da comunicação, comunicação intercultural e estudos lusótonos.

Ohttps://orcid.org/0000-0003-3072-2904

sesm@ics.uminho.pt

mail: peixoto@galveias net
Sta edição é dedicada, parcialmente, aos "Diálogos literários na Lusofonia: Portugal, Brasil, Angola, Cabo Verde, Moçambique e outras literaturas lusófonas". Estas outras literaturas poderiam incluir, por exemplo, a produção de Goa (Índia) ou até mesmo de Macau (China), territórios onde, absolutamente minoritária e quase esquecida, a língua portuguesa ainda resiste, inclusive literariamente. Em Macau, por exemplo, circula diariamente um jornal em língua portuguesa... isso, para não citarmos o Timor ou a Guiné Bissau.

O conceito de "lusofonia", contudo, embora valioso e constantemente revalorizado, é também contestado por muitos, motivo pelo qual entendemos que este enquadramento do tema seria interessante. A coletânea não possui muitos artigos: aparentemente, o tema ainda tem pequena circulação na academia, ao menos no Brasil; e alguns dos artigos recebidos nem sempre se enquadraram nos parâmetros propostos. De qualquer modo, pequena em número, maior em qualidade, a série de textos que se segue abre um horizonte que, parece-me, pode e deve ser mais explorado pelos pesquisadores brasileiros.

O texto que abre a série é de Moisés Martins: a partir da Universidade de Braga, ele mantém extenso intercâmbio com pesquisadores brasileiros e lusófonos de todos os continentes. Aqui, ele propõe justamente a discussão de fundo sobre a lusofonia, tema que lhe é caro e ao qual se dedica especialmente.

Segue-se um artigo assinado por Antonio Carlos Hohlfeldt. Com Moisés Martins e José Luís Peixoto, Hohlfeldt foi o editor desta série de estudos. Professor na PUCRS, no Brasil, ele se dedica aos estudos sobre a história do jornalismo no 
universo luso-brasileiro. Aqui, fez um recorte específico para pensar as contribuições do jornalismo à literatura de cada uma das antigas colônias de expressão portuguesa.

Moçambique se destaca na reflexão maior deste espaço. “O canto na cidade calada à força: Poder simbólico na poesia anticolonial moçambicana”, como indica o título do artigo, faz um apanhado de contribuições de poetas moçambicanos que abriram os debates em torno da identidade do país. 0 artigo de Luana Soares de Souza se completa com o de Cláudia Mentz Martins e Neiva Kampff Garcia, em "Águas que desenham Moçambique", que discutem uma literatura mais contemporânea, a partir da obra de Mia Couto que, embora em prosa, é marcadamente poética. O mesmo Mia Couto é tema de "O poeta, o louco e a criança: Companheiros de brincriação e enquadramentos táticos de sobrevivência", modo criativo com que Breno Fernandes discute um dos mais conhecidos textos do escritor moçambicano de larga difusão no Brasil.

Os demais artigos, de certo modo, ecoam as preocupações expressas pelo texto de abertura: Fernanda Vilar discute "A África no cânone na literatura lusófona pós-colonial", refletindo sobre o dinamismo (ou falta de) dos PALOPs, enquanto Ricardo André Ferreira Martins e Keissy Guarianto Carvelli, a partir da poesia de Paulo Leminski, discutem sobre conceitos de língua e dialeto, temas sempre lembrados quando pensamos essas literaturas, seja porque boa parte das atuais nações africanas, embora tenham no português seu idioma oficial, nem sempre o possuem como sua língua mais falada; seja porque, como no Brasil, embora guardemos uma única língua, as variantes deste idioma por vezes fazem alguns mais apressados rechaçarem o conceito de variantes e imaginar novos idiomas...

Em contraste, mas ampliando a perspectiva deste dossiê, temos dois textos extremamente oportunos, o de Lucas Bento Pugliesi, chamado "Clarezas (e obscuridades) d'O desertor de Silva Alvarenga" e o de Ricardo Mendes Matos a respeito de "A poesia portuguesa no Samba de Roda do Recôncavo Baiano", que trazem perspectivas de estudos no campo da literatura comparada.

Por certo, a proposta deste espaço poderia ter sido bem mais explorada. Mas fica aberta a picada para as próximas edições. Trata-se de um universo tão variado quanto rico, justamente graças a esta diversidade. 